\title{
Explosive Rise in Viral Infections Through Meat-Sellers
}

\author{
Braira Wahid, ${ }^{1,2,}{ }^{*}$ Muhammad Wasim, ${ }^{3}$ Muhammad Waqar, ${ }^{1,2}$ Sajjad, ${ }^{1,4}$ Khansa Wahid, ${ }^{5}$ and \\ Muhammad Idrees ${ }^{1,2,4,6}$ \\ ${ }^{1}$ Genome Centre for Molecular Based Diagnostics and Research, Al-Sudais Plaza Abdalian Cooperative Society, Lahore, Pakistan \\ ${ }^{2}$ Centre for Applied Molecular Biology (CAMB), 87-West Canal Bank Road Thokar Niaz Baig, University of the Punjab, Lahore, Pakistan \\ ${ }^{3}$ Department of Medicine, Khyber Teaching Hospital, Peshawar, Khyber Pakhtunkhwa, Pakistan \\ ${ }^{4}$ Hazara University Mansehra, Khyber Pakhtunkhwa, Pakistan \\ ${ }^{5}$ Department of Chemistry, Lahore College for Women University, Lahore, Pakistan \\ ${ }^{6}$ Division of Molecular Virology and Diagnostics Center of Excellence in Molecular Biology (CEMB), 87-West Canal Bank Road Thokar Niaz Baig, University of the Punjab, \\ Lahore, Pakistan \\ "Corresponding author: Braira Wahid, Genome Centre for Molecular Based Diagnostics and Research, Al-Sudais Plaza Abdalian Cooperative Society, Lahore, Pakistan. Tel: \\ +92-4235219020, E-mail: brairawahid@gmail.com
}

Received 2018 March 19; Revised 2018 May 01; Accepted 2018 May 05.

Keywords: Butchers, Meat, HCV, HBV, HIV

\section{To the editor,}

In developing countries, inadequate meat processing facilities, and unhygienic environments at slaughterhouses cause occupational hazards to workers, meatconsumers, or anyone exposed to that environment. Multiple flaws e.g. inadequate training, inadequate infrastructure, poor hygiene etc. contaminate the meat and transmit pathogens. The transmission of viral infections through meat-sellers is one of the most neglected public-health risks. This mode of transmission is least focused in the literature, while occupational transmission of viruses is always discussed in context of trading of diseased animal meat. However, there is not a single study that highlights the role played by butchers (who themselves are positive for multiple viral infections) in transmission of viruses.

The team of researchers working at the genome centre at molecular based diagnostics and research, Lahore Pakistan, observed an unexpected surge in human immunodeficiency virus (HIV) and hepatitis C virus (HCV) cases from one particular area during the recent week. In an attempt to figure the reason behind the transmission of this life-threatening virus, the researchers visited an abattoir and collected blood samples of meat-processing workers, who had cuts on their hands while slaughtering animals. The researchers screened blood samples to test the presence of prevalent viruses, including Hepatitis B Virus (HBV), HCV, and HIV. Their blood samples were tested at the laboratory using the SACACE kit (Sacace Biotechnologies, Como, Lombardia) and cepheid smart cycler II thermal cycler automated real-time polymerase Chain reaction system (Boston Industries, Inc. Walpole USA) for viral quan- titation. The researchers observed that two butchers had significantly high viral load of HIV, HBV, and HCV, whereas, some butchers were positive for hepatitis A virus (HAV) and hepatitis E virus (HEV) (Figure 1).

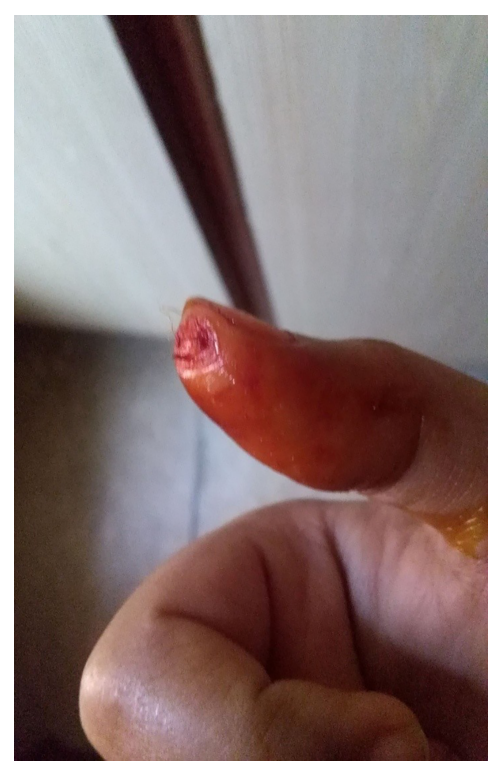

Figure 1. Open cut observed on the hand of an HIV- and HCV-positive butcher

Butchers use a common ham-cutting machine that causes hand injuries with frequent bleeding, and the meat contaminated with the blood of infected butchers is transmitted to meat consumers and their household. Although, 
evidence for viral transmission through food are sparse yet the current observation highlighted the possibility of spread of viruses through slaughter-houses and butchers. The most common possible high risk groups were hospitalbased e.g. healthcare-professionals, surgeons, doctors, and nurses yet viral transmission through butchers have always been downplayed. Limited evidence has reported the outbreaks of HEV and HAV by meat products (1-4).

In conclusion, butchers should be periodically screened against different viral infections because they are in contact with healthy citizens as well as immunocompromised citizens while selling their meat. Their risky practices, such as knife-cuts and blood-letting, is posing a serious threat to the lives of the entire community, which is why improvements should be made to facilities and practices in all abattoirs.

\section{Footnotes}

Conflict of Interests: None. Funding/Support: None.

\section{References}

1. Traore KA, Ouoba JB, Huot N, Rogee S, Dumarest M, Traore AS, et al. Hepatitis E Virus Exposure is Increased in Pork Butchers from Burkina Faso. Am J Trop Med Hyg. 2015;93(6):1356-9. doi: 10.4269/ajtmh.15-0321. [PubMed: 26438027]. [PubMed Central: PMC4674258].

2. Velebit B, Radin D, Teodorovic V. Transmission of common foodborne viruses by meat products. Proc Food Sci. 2015;5:304-7. doi: 10.1016/j.profoo.2015.09.069.

3. Ola SO, Otegbayo JA, Yakubu A, Odaibo GN, Olaleye DO. Nigerian butchers and hepatitis B virus infection. Trop Gastroenterol. 2008;29(1):32-4. [PubMed: 18564665].

4. Ola SO, Otegbayo JA, Yakubu A, Odaibo GN, Olaleye DO. Risk of hepatitis B virus in the slaughter house. Trop Doct. 2008;38(4):249-50. doi 10.1258/td.2008.070419. [PubMed: 18820203]. 